\title{
Serological evidence of equine influenza virus in horse stables in Kaduna, Nigeria
}

\author{
Glement A. MESEKO ${ }^{1 \#}$, David O. EHIZIBOLO ${ }^{1 * \#}$, Edith G. NWOKIKE ${ }^{2}$ and \\ Yiltawe S. WUNGAK ${ }^{1}$ \\ ${ }^{1}$ Viral Research Division, National Veterinary Research Institute, P.M.B. 01 Vom, Nigeria \\ ${ }^{2}$ Equitation Wing, Nigerian Defence Academy, Kaduna, Nigeria
}

\begin{abstract}
Equine influenza virus (EIV) is a major cause of acute respiratory diseases in horses in most parts of the world that results in severe economic losses. Information on the epidemiology of EIV in tropical Africa is scanty. An enzyme-linked immunosorbent assay (ELISA) was used to detect the presence of influenza A virus nucleoprotein (NP) in 284 horse sera in Kaduna State, Northern Nigeria. The ELISA-positive sera were further examined for hemagglutination inhibition (HI) antibodies to two strains each of H3N8 and H7N3 subtypes of influenza A virus. The results showed that antibodies against influenza A virus nucleoprotein were detected in 60.9\% (173 of 284) of horses examined by NP-ELISA. Equine $\mathrm{H3}$ and $\mathrm{H} 7$ subtypes were detected in 60\% (21 of 35) and 20\% (7 of 35) of horse sera respectively across the stables. Adequate quarantine of all imported horses, a national equine influenza surveillance plan and an appropriate EIV control program in Nigeria are recommended to safeguard the large horse population.
\end{abstract}

Key words: equine, influenza virus, Nigeria, stables

\author{
J. Equine Sci. \\ Vol. 27, No. 3 \\ pp. 99-105, 2016
}

Equine influenza is a highly contagious, infectious upper respiratory disease of horses characterized by anorexia, pyrexia, dypsnea, dry cough and nasal discharges $[19,20$, 41]. It is caused by the equine influenza virus (EIV), a respiratory pathogen of horses and other equidae belonging to the Orthomyxoviridae family (genus Influenza A).

Two EIV subtypes H7N7 (equine-1) and H3N8 (equine-2) are recognized to have been established in horses, co-circulating for nearly two decades [39]. The H7N7 subtype which was first isolated in horses in 1956 [35] has not been in circulation since 1978 [38], however, serological evidence of this virus subtype has been reported in India in the recent past [34]. The H3N8 (avian-origin influenza) which was first isolated in 1963 [41] has continued to spread panzootically among horses $[9,24]$. To date, H3N8 subtype have been the cause of all outbreaks of EI since 1979 [8]. Evidence of the H3N8 subtype in dogs [7, 12] and pigs [37] has been

Received: February 12, 2016

Accepted: June 10, 2016

*Corresponding author. e-mail: kingdavid_e@yahoo.com

\#These authors contributed equally to this wotk.

(C)2016 Japanese Society of Equine Science

This is an open-access article distributed under the terms of the Creative Commons Attribution Non-Commercial No Derivatives (by-nc-nd) License $<$ http://creativecommons.org/licenses/by-nc-nd/4.0/>. documented and $\mathrm{H} 3 \mathrm{~N} 8$ experimental infection has also been demonstrated in cats [33].

Pneumonia usually occurs in infected animals following secondary bacterial infection [30]. The disease is less fatal in the absence of pneumonia; however, an outbreak may cause suboptimal performance and devastating economic losses in the equine industry [8, 29, 42]. It is transmitted through direct contact and inhalation, with an incubation period of 2-5 days and an extremely high mortality of $>90 \%$ $[31,43]$.

EI is endemic in Europe and North America and major outbreaks have been recorded in the recent past in Asia, that is, in China, Hong Kong, Japan, India and Mongolia [10, 29, 40, 44, 45]; in Africa, that is, in Nigeria, South Africa and Algeria [2, 11, 17]; in Australia [32] and in South America [25] affecting tens of thousands of horses. Recently, an outbreak of EI was confirmed in several horses between the ages of 1 to 7 years at a championship horse show in Oregon, U.S.A. [36]. To date, New Zealand and Iceland are reported to be free of EIV [25]. Information on the epidemiology of EIV in tropical Africa is scanty. In Nigeria, the first known outbreak of EIV occurred in 1991, among horses from different parts of the country congregated at the Ibadan polo tournament in the south western region [2]. From available records, some of the horses stabled in 


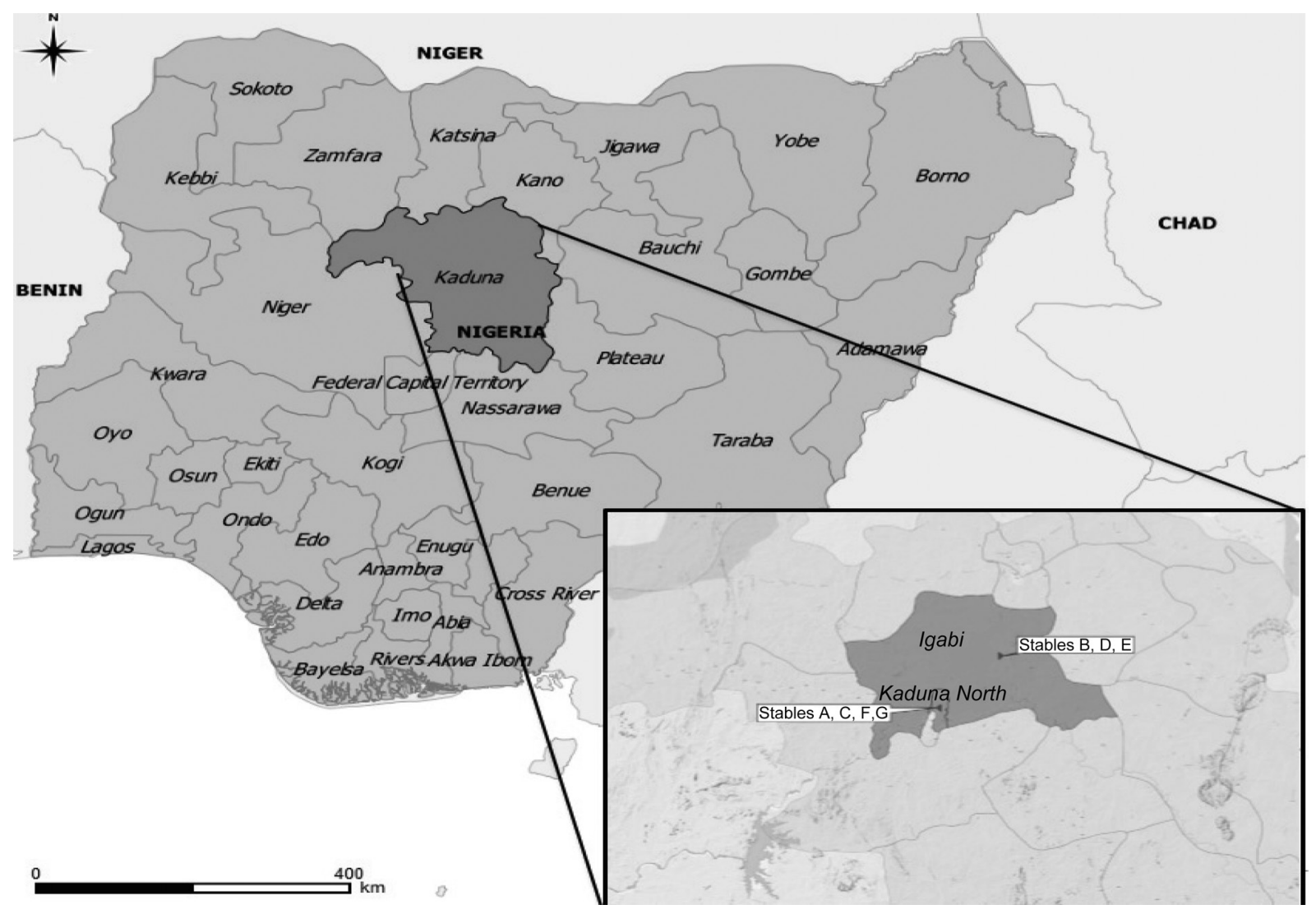

Fig. 1. Map of Nigeria showing study area and stable locations.

temporary shelters during the tournament were said to have been recently imported from Argentina and the U.K. This outbreak was caused by the H3N8 subtype. Although there had not been any reported EIV outbreak in Nigeria since the first outbreak, serological evidence of EIV subtypes H3 in horses [3, 27] and EIV subtype $\mathrm{H} 7$ in horses, pigs, chickens and humans $[1,25,26]$ have been documented.

Natural human infection with equine influenza is rare, but experimental infection of human volunteers with equine influenza virus has been demonstrated [14]. A study has also shown an antigenic relationship between the equine and the Hong Kong human variants of the influenza subtype H2 virus [15]. Despite the occasional identification of seropositive individuals with occupational exposure there is currently little evidence of human infection with equine influenza $[5,18]$.

The emergence in 2009 of pandemic influenza from swine and its continuous evolution at the human-animal interface also underscore the need for sustained surveillance and monitoring of influenza virus in various susceptible species [21]. Only partial serological data are available for EIV in Nigeria, and serological testing has usually only been within specific areas in the south western Nigeria particu- larly during polo tournaments. Moreover, there is bias due to the fact that samples obtained usually comes from horses within polo club stables. In this study, we carried out a cross-sectional serological survey of equine influenza in some horse stables within government security institutions, private institutions (polo clubs) and a traditional institution in Kaduna metropolis, north western Nigeria.

\section{Materials and Methods}

\section{Description of study area and stable management}

Kaduna state is located in the north western region of Nigeria, in the Northern Guinea Savannah zone (Fig. 1). Horses in seven different stables (designated $A-G$ ) belonging to government security institutions $(n=2)$, private organizations $(n=4)$ and a traditional institution $(n=1)$ located within Kaduna metropolis, Nigeria were used for the study in January 2013. These stables were under intensive-semi-intensive management accommodating approximately 30-200 horses each. The horses were kept primarily for special ceremonial activities, trainings, crowd control, racing competition and polo. Routine veterinary care was provided for horses at the stables except stable 
$\mathrm{G}$, and no preventive vaccinations were routinely applied against EI or any animal influenza in Nigeria.

\section{Sample collection}

Using the principles of convenience sampling, about $50 \%$ of the total number of horses in each stable were selected for blood sampling. A total of 284 horses of all ages (2-22 years), different breeds and of both sexes representing these stables were sampled under proper restraint. Approximately $10 \mathrm{ml}$ of blood was collected from each horse into properly labelled Vacutainer tubes and transported to the virology laboratory in National Veterinary Research Institute, Vom, Nigeria. The blood samples were allowed to clot, and then centrifuged in the laboratory at 2,000 rpm for $5 \mathrm{~min}$. Sera were separated into properly labelled cryovials, and stored at $-20^{\circ} \mathrm{C}$ until tested.

\section{Test procedure: Enzyme-linked immunosorbent assay (ELISA)}

An influenza A virus antibody ELISA test kit (IDEXX, Montpellier, France) was used according to the manufacturer's instructions for the measurement of the relative level of group-specific antibodies to influenza A nucleoprotein in the horse serum tested. Briefly, the test plate was pre-coated with influenza A viral nucleoprotein antigen. Upon incubation of the diluted samples (1/10), influenza A-specific antibodies form a complex with the coated nucleoprotein antigen. After washing away unbound material, an anti-influenza A nucleoprotein monoclonal antibody enzyme conjugate was added to the wells. If the sample did not contain influenza A nucleoprotein antibodies, the conjugate bound to the influenza A antigen on the plate. If antibodies to influenza A virus were present in the sample, the anti-influenza A nucleoprotein conjugate was blocked from binding to the antigen. Unbound materials were washed away and a colorimetric reaction was developed with the addition of an enzyme substrate. Optical density reading was performed with a spectrophotometer and a $650 \mathrm{nM}$ filter. Results were evaluated based on the mean of sample to negative control mean $(\mathrm{S} / \mathrm{N})$ ratio. Samples with $\mathrm{S} / \mathrm{N}$ values $<0.60$ were considered positive for antibodies to influenza A virus.

\section{Hemagglutination-inhibition (HI) test}

Due to limited availability of the required reagents, representative sera samples that were positive for influenza $A$ virus antibodies by NP-ELISA were selected $(n=35)$ for the $\mathrm{HI}$ assay in order to determine the influenza A virus subtype.

Treatment of sera with a receptor-destroying enzyme (RDE): To remove nonspecific hemagglutinin, test sera were treated with RDE (Influenza Reagent Resources (IRR), Centers for Disease Control and Prevention (CDC), U.S.A.) according to published methods $[6,11,25]$ with some modifications. RDE was reconstituted with physiological saline according to the provided instructions; $0.9 \mathrm{~m} l$ of RDE was mixed with $0.3 \mathrm{~m} l$ of test serum and incubated overnight at $37^{\circ} \mathrm{C}$ in a water bath. After overnight incubation the mixture was heated at $56^{\circ} \mathrm{C}$ for 30 min to inactivate remnants of $\mathrm{RDE}$ in the treated sera. Serum samples were allowed to cool to room temperature and $1.8 \mathrm{~m} l$ of normal saline was added to give a final dilution of $1: 10$.

Hemardsorption with chicken red blood cells (RBCs): Each RDE-treated sample was added to packed RBCs in centrifuge tubes at a ratio of 20:1 and thoroughly mixed and then incubated at $4^{\circ} \mathrm{C}$ for $1 \mathrm{hr}$, with intermittent mixing to resuspend red cells. The red cells were allowed to settle by gravitation and the supernatant was collected into cryovials and used for HI testing.

The test was performed as described by Hsiung [13] with some modifications using a U-bottom microtitre plate by first carrying out hemagglutination (HA) to appropriately determine 4HA units of the $\mathrm{H} 3 \mathrm{~N} 2$ and $\mathrm{H} 7 \mathrm{~N} 3$ antigens used (OIE/FAO reference laboratory, Instituto Zooprofilattico Sperimentale delle Venezie, Padova, Italy). The HI test targets cross-reactivity of hemagglutinin protein of avian $\mathrm{H} 7$ and $\mathrm{H} 3$ origin. Treated sera were diluted serially in twofold with PBS while 4HA units each of reconstituted antigens for $\mathrm{H} 3$ and $\mathrm{H} 7$, which had been predetermined was added, and the plate was shaken and incubated at room temperature $\left(27^{\circ} \mathrm{C}\right)$ for $30 \mathrm{~min}$ to allow the reaction to take place. Pooled chicken RBCs ( $1 \%$ suspension) were added and incubated for $30 \mathrm{~min}$ room temperature $\left(27^{\circ} \mathrm{C}\right)$. The test was read by tilting the microtitre plate at an angle to observe RBCs streaming at the bottom of the well. The HI titre was taken as the highest dilution of serum with complete inhibition of agglutination in a twofold serial dilution of the original sera.

\section{Results}

Data regarding the age range (2-22 years), sex, breeds and vaccination history of horses sampled from different stables (designated A-G) were recorded (Table 1). A total of 284 serum samples collected from 7 stables in Kaduna metropolis were analyzed. One hundred and seventythree $(60.9 \%)$ tested positive for antibodies against EIV A by NP-ELISA. Stable B had the highest seroprevalence $(85.7 \%)$ and stable $\mathrm{C}$ had the lowest (27.3\%). Thirty-five representative ELISA reactors were randomly selected for HI assay and the results are presented in Table 2. EIV A subtypes $\mathrm{H} 3$ and $\mathrm{H} 7$ were detected in the horse stables in Kaduna metropolis. The results show that the H3 subtype was more prevalent with $21(60 \%)$ of the tested sera positive with an HI titre of $3 \log 2(8-256)$, while $7(20 \%)$ had an HI titre of $3 \log 2$ to $4 \log 2(8-16)$ for the H7 subtype. 
Table 1. Detection of influenza a virus antibodies by ELISA in horse stables in Kaduna metropolis, Nigeria

\begin{tabular}{|c|c|c|c|c|c|c|c|}
\hline \multirow{2}{*}{ Stable } & \multirow{2}{*}{$\begin{array}{c}\text { No. of } \\
\text { samples }\end{array}$} & \multirow{2}{*}{ Breed } & \multicolumn{2}{|c|}{ Sex } & \multirow{2}{*}{$\begin{array}{l}\text { Age (years) } \\
\text { range }\end{array}$} & \multirow{2}{*}{$\begin{array}{l}\text { Vaccination } \\
\text { history }\end{array}$} & \multirow{2}{*}{$\begin{array}{l}\text { EI A ELISA } \\
\text { positive (\%) }\end{array}$} \\
\hline & & & Male & Female & & & \\
\hline A & 17 & Mixed* & 10 & 7 & $4-10$ & NV & $14(82.3)$ \\
\hline B & 28 & Exotic & 12 & 16 & $2-9$ & NV & $24(85.7)$ \\
\hline $\mathrm{C}$ & 22 & Local & 15 & 7 & $6-22$ & NV & $6(27.3)$ \\
\hline $\mathrm{D}$ & 93 & Exotic & 22 & 71 & $3-13$ & NV & $46(49.5)$ \\
\hline $\mathrm{E}$ & 15 & Exotic & 3 & 12 & $3-11$ & $\mathrm{NV}$ & $11(73.3)$ \\
\hline F & 17 & Local & 16 & 1 & $4-15$ & NV & $11(64.7)$ \\
\hline G & 92 & Local & 22 & 70 & $2-17$ & NV & $61(66.3)$ \\
\hline Total & 284 & & & & & & $173(60.9)$ \\
\hline
\end{tabular}

*10 exotic and 7 local breeds; NV: not vaccinated.

Table 2. EIV subtypes distribution in horse sera tested in Kaduna metropolis by the hemagglutination inhibition test

\begin{tabular}{lccccccccc}
\hline \multirow{2}{*}{ Subtypes } & \multicolumn{8}{c}{ HI titre-twofold sample dilution } & \multirow{2}{*}{ Total } \\
\cline { 2 - 9 } & $1: 2$ & $1: 4$ & $1: 8$ & $1: 16$ & $1: 32$ & $1: 64$ & $1: 128$ & $1: 256$ & \\
\hline H3 & - & - & 2 & 3 & 4 & 5 & 3 & 4 & 21 \\
H7 & - & - & 5 & 2 & - & - & - & - & 7 \\
\hline
\end{tabular}

\section{Discussion}

The ELISA results in this report show that $173(60.9 \%)$ of the horses in the 7 tested stables in Kaduna metropolis were positive for antibodies against EIV A. Further analysis on some randomly selected ELISA reactors $(n=35)$ with an $\mathrm{HI}$ assay revealed the presence of EI A subtypes H3 ( $\mathrm{n}=21)$ and $\mathrm{H} 7(\mathrm{n}=7)$. Seven ELISA-positive sera had an antibody titre of less than $1 \log 2$ for both $\mathrm{H} 7$ and H3 in the HI assay, which may not be unrelated to the high sensitivity of the ELISA compared with HI. However, these samples could be tested for other HA subtypes when available to our laboratory. The detection of EI A virus antibodies by two independent serological tests is an indication of EI infection past or present in the stables sampled. EIV subtypes H3 and $\mathrm{H} 7$ have been previously reported among polo horses in south western region of Nigeria [4, 28]. The diagnosis of EIV could be based on virus isolation in embryonated eggs from horses with acute infection. However, the demonstration of an antibody response is an evidence of subclinical infection. Due to limited laboratory resources, we were only able to select a few ELISA-positive samples for HA to determine prevailing subtypes. Test sera were first treated with RDE to remove nonspecific inhibitors according to the OIE protocol. Other limitations in this study include the possibility that RDE does not always inactivate nonspecific inhibitors that may occur at low levels in horse sera [6]. Though potassium periodate is recommended as the best destroyer of nonspecific inhibitors, but it was not available to us. Also lacking were the equine strains of $\mathrm{H} 3$ and $\mathrm{H} 7$ antigens, which is why we used avian strain subtypes. However by including appropriate internal positive and negative controls we sought to validate both the ELISA and HI tests. Furthermore, cross-reactivity of antigens and antisera has been demonstrated in influenza serology and the species in which antibodies or antigens are raised influences the degree of cross-reactivity. Given that all influenza A subtypes (H1-16) have avian progenitors the HI test was able to detect cross-reactive subtype-specific activities at low levels especially for H7. Nevertheless, the HI titre could probably be higher if species-specific strains H7N7 (equine-1) and H3N8 (equine-2) were used as antigens in the assay.

This study is significant in this field because of its use of a large number of horses and because it shows the probability of two EIV strains circulating in this apart of Nigeria, which requires further investigation. Equine Influenza could have deleterious health and economic consequences for the boisterous equestrian activities in the country.

The epidemiology of EI in Nigeria could be linked to importation of horses from EIV endemic countries as previously described in south western Nigeria in 1991 amongst polo horses [2]. Molecular studies on the three H3N8 subtypes independently isolated shows that their genes are equine in origin and that the hemagglutinin (HA) glycoprotein is most closely related to European and Scandinavian isolates [3]. Although there has been no EIV outbreak reported in Nigeria since 1991, serological evidence of the disease has been demonstrated in horses and donkeys in 
some parts of the country [4, 28].

In countries like South Africa and India where major epidemics have been recorded in the past, infections were introduced by the importation of sub clinically infected horses from Europe and America as confirmed by the close antigenic relationships with isolates from those countries [16]. Polo tournaments and other equestrian activities are popular in Nigeria often attracting horses from far and near some of which are imported and kept near together with large numbers of human spectators. Though natural human infection with equine influenza is rare, experimental infection of human volunteers with equine influenza virus has been demonstrated [14]. A study has also shown an antigenic relationship between the equine and the Hong Kong variants of the influenza subtype $\mathrm{H} 2$ virus [15]. Vaccination against EI is an effective method of disease control in developed countries; however, the importation of unregulated horses in conjunction with inadequate quarantine procedures could result into major outbreaks through the introduction of exotic viral strains with significant health and economic consequences. Other animal influenza viruses particularly swine [22] and avian [23] influenza viruses, have been reported at the human-animal interface in Nigeria. Therefore, the risk of exposure and virus reassortment of the equine, swine, avian and human influenzas if and where they co-circulate is a cause for concern particularly because of the existing poor level of biosecurity. There are no national surveillance programs for EIV in Nigeria predominantly due to lack of funding. Furthermore, only partial serological data are available for EIV in Nigeria, and serological testing is usually only performed for a specific location and specific research studies. It is therefore necessary to put in place an EI national surveillance plan with recommendations for an appropriate control program to safeguard the large population of horses in Nigeria.

\section{Acknowledgment}

We are grateful to the management of the stables for granting us the permission to carry out this study. The support of the Executive Director of the National Veterinary Research Institute, Vom, Nigeria is highly appreciated.

\section{References}

1. Adeniji, J.A., Adu, F.D., Baba, S.S., Ayoade, G.O., Owoade, A.A., and Tomori, O. 1993. Influenza A and B antibodies in pigs and Chicken population in Ibadan metropolis, Nigeria. Trop. Veterinarian 11: 39-45.

2. Adeyefa, C.A.O., and McCauley, J.W. 1994. Outbreak of equine influenza in polo horses in Ibadan, Nigeria: virus isolation, clinical manifestation and diagnosis. Vet. Rec.
134: 683-684. [Medline] [CrossRef]

3. Adeyefa, C.A.O., Hamblin, C., Cullinane, A.A., and McCauley, J.W. 1996a. Nationwide serological survey of equine influenza in Nigeria. Rev. Elev. Med. Vet. Pays Trop. 49: 24-27. [Medline]

4. Adeyefa, C.A.O., James, M.L., and McCauley, J.W. 1996b. Antigenic and genetic analysis of equine influenza viruses from tropical Africa in 1991. Epidemiol. Infect. 117: 367-374. [Medline] [CrossRef]

5. Alexander, D.J., and Brown, I.H. 2000. Recent zoonoses caused by influenza A viruses. Rev. Off. Int. Epizoot. 19: 197-225. [Medline] [CrossRef]

6. Ananthanarayan, R., and Paniker, C.K. 1960. Non-specific inhibitors of influenza viruses in normal sera. Bull. World Health Organ. 22: 409-419. [Medline]

7. Crawford, P.C., Dubovi, E.J., Castleman, W.L., Stephenson, I., Gibbs, E.P., Chen, L., Smith, C., Hill, R.C., Ferro, P., Pompey, J., Bright, R.A., Medina, M.J., Johnson, C.M., Olsen, C.W., Cox, N.J., Klimov, A.I., Katz, J.M., and Donis, R.O. 2005. Transmission of equine influenza virus to dogs. Science 310: 482-485. [Medline] [CrossRef]

8. Gildea, S., Fitzpatrick, D.A., and Cullinane, A. 2013. Epidemiological and virological investigations of equine influenza outbreaks in Ireland (2010-2012). Influenza Other Respi. Viruses 7(Suppl 4): 61-72. [Medline] [CrossRef]

9. Gildea, S., Quinlivan, M., Arkins, S., and Cullinane, A. 2012. The molecular epidemiology of equine influenza in Ireland from 2007-2010 and its international significance. Equine Vet. J. 44: 387-392. [Medline] [CrossRef]

10. Guo, Y., Wang, M., Zheng, G.S., Li, W.K., Kawaoka, Y., and Webster, R.G. 1995. Seroepidemiological and molecular evidence for the presence of two H3N8 equine influenza viruses in China in 1993-94. J. Gen. Virol. 76: 2009-2014. [Medline] [CrossRef]

11. Guthrie, A.J., Stevens, K.B., and Bosman, P.P. 1999. The circumstances surrounding the outbreak and spread of equine influenza in South Africa. Rev. Off. Int. Epizoot. 18: 179-185. [Medline] [CrossRef]

12. Hayward, J.J., Dubovi, E.J., Scarlett, J.M., Janeczko, S., Holmes, E.C., and Parrish, C.R. 2010. Microevolution of canine influenza virus in shelters and its molecular epidemiology in the United States. J. Virol. 84: 12636-12645. [Medline] [CrossRef]

13. Hsiung, G.D. 1973. Diagnostic virology: an illustrated handbook, pp. 26-34, 172. Yale University Press, New Haven.

14. Kasel, J.A., Alford, R.H., Knight, V., Waddell, G.H., and Sigel, M.M. 1965. Experimental Infection of Human Volunteers with Equine Influenza Virus. Nature 206: 41-43. [Medline] [CrossRef]

15. Kasel, J.A., Fulk, R.V., and Couch, R.B. 1969. Communications. Antigenic relationship between the equine and the Hong Kong human variant of influenza type A2 virus. $J$. Immunol. 102: 530-532. [Medline] 
16. Kawaoka, Y., Bean, W.J., and Webster, R.G. 1989. Evolution of the hemagglutinin of equine $\mathrm{H} 3$ influenza viruses. Virology 169: 283-292. [Medline] [CrossRef]

17. Laabassi, F., Lecouturier, F., Amelot, G., Gaudaire, D., Mamache, B., Laugier, C., Legrand, L., Zientara, S., and Hans, A. 2015. Epidemiology and genetic characterization of $\mathrm{H} 3 \mathrm{~N} 8$ equine influenza virus responsible for clinical disease in Algeria in 2011. Transbound. Emerg. Dis. 62: 623-631. [Medline] [CrossRef]

18. Larson, K.R., Heil, G.L., Chambers, T.M., Capuano, A., White, S.K., and Gray, G.C. 2015. Serological evidence of equine influenza infections among persons with horse exposure, Iowa. J. Clin. Virol. 67: 78-83. [Medline] [CrossRef]

19. Livesay, G.J., O’Neill, T., Hannant, D., Yadav, M.P., and Mumford, J.A. 1993. The outbreak of equine influenza (H3N8) in the United Kingdom in 1989: diagnostic use of an antigen capture ELISA. Vet. Rec. 133: 515-519. [Medline] [CrossRef]

20. van Maanen, C., and Cullinane, A. 2002. Equine influenza virus infections: an update. Vet. Q. 24: 79-94. [Medline] [CrossRef]

21. Meseko, C., Olaleye, D., Capua, I., and Cattoli, G. 2014. Swine influenza in sub-saharan Africa-current knowledge and emerging insights. Zoonoses Public Health 61: 229-237. [Medline] [CrossRef]

22. Meseko, C.A., Odaibo, G.N., and Olaleye, D.O. 2014. Detection and isolation of 2009 pandemic influenza A/ H1N1 virus in commercial piggery, Lagos Nigeria. Vet. Microbiol. 168: 197-201. [Medline] [CrossRef]

23. Monne, I., Meseko, C., Joannis, T., Shittu, I., Ahmed, M., Tassoni, L., Fusaro, A., and Cattoli, G. 2015. Highly pathogenic avian influenza A (H5N1) virus in poultry, Nigeria. Emerg. Infect. Dis. 21: 1275-1277. [Medline] [CrossRef]

24. Newton, J.R., Daly, J.M., Spencer, L., and Mumford, J.A. 2006. Description of the outbreak of equine influenza (H3N8) in the United Kingdom in 2003, during which recently vaccinated horses in Newmarket developed respiratory disease. Vet. Rec. 158: 185-192. [Medline] [CrossRef]

25. OIE (World Organisation for Animal Health) 2015. Equine Influenza. Available at http:// www.oie.int/fileadmin/ home/eng/health_standards/tahm/2.05.07_EQ_INF.pdf (accessed on 6 May, 2015).

26. Olaleye, O.D., Omilabu, S.A., Baba, S.S., and Fagbami, A.H. 1990. Haemagglutination-inhibiting (HI) antibodies against strains of influenza A virus in horse and pig sera in Nigeria. J. Hyg. Epidemiol. Microbiol. Immunol. 34: 365-370. [Medline]

27. Olusa, T.A.O., and Adeyefa, C.A.O. 2009. Serosurveillance of equine H3 influenza virus in horses in Ibadan, Nigeria. Trop. Veterinarian 27: 15-19.

28. Olusa, T.A.O., Adegunwa, A.K., Aderonmu, A.A., and Adeyefa, C.A.O. 2010. Serologic evidence of equine H7 influenza virus in polo horses in Nigeria. Sci. World J. 5: 17-19.

29. Powell, D.G., Watkins, K.L., Li, P.H., and Shortridge, K.F. 1995. Outbreak of equine influenza among horses in Hong Kong during 1992. Vet. Rec. 136: 531-536. [Medline] [CrossRef]

30. Sarasola, P., Taylor, D.J., Love, S., and McKellar, Q.A. 1992. Secondary bacterial infections following an outbreak of equine influenza. Vet. Rec. 131: 441-442. [Medline] [CrossRef]

31. Satou, K., and Nishiura, H. 2006. Basic reproduction number for equine influenza virus A (H3N8) epidemic in race-horse facilities in Japan, 1971. J. Equine Vet. Sci. 26: 310-316. [CrossRef]

32. Schemann, K., Firestone, S.M., Taylor, M.R., Toribio, J.A., Ward, M.P., and Dhand, N.K. 2012. From the horse's mouth: perceptions of the management of the 2007 equine influenza outbreak in Australia. Transbound. Emerg. Dis. 59: 503-516. [Medline] [CrossRef]

33. Su, S., Wang, L., Fu, X., He, S., Hong, M., Zhou, P., Lai, A., Gray, G., and Li, S. 2014. Equine influenza A (H3N8) virus infection in cats. Emerg. Infect. Dis. 20: 2096-2099. [Medline] [CrossRef]

34. Singh, G. 1994. Characterization of A/eq-1 virus isolated during the equine influenza epidemic in India. Acta Virol. 38: 25-26. [Medline]

35. Sovinova, O., Tumova, B., Pouska, F., and Nemec, J. 1958. Isolation of a virus causing respiratory disease in horses. Acta Virol. 2: 52-61. [Medline]

36. The Horse 2015. Equine influenza-USA: (OREGON). http// www.thehorse.com/articles/35978/equine-influenzareported-in-oregon (accessed on 25 June, 2015).

37. Tu, J., Zhou, H., Jiang, T., Li, C., Zhang, A., Guo, X., Zou, W., Chen, H., and Jin, M. 2009. Isolation and molecular characterization of equine H3N8 influenza viruses from pigs in China. Arch. Virol. 154: 887-890. [Medline] [CrossRef]

38. Tůmová, B. 1980. Equine influenza--a segment in influenza virus ecology. Comp. Immunol. Microbiol. Infect. Dis. 3: 45-59. [Medline] [CrossRef]

39. Tůmová, B., Easterday, B.C., and Stumpa, A. 1972. Simultaneous occurrence of A-equi-1 and A-equi-2 infleunza viruses in a small group of horses. Am. J. Epidemiol. 95: 80-87. [Medline]

40. Virmani, N., Bera, B.C., Singh, B.K., Shanmugasundaram, K., Gulati, B.R., Barua, S., Vaid, R.K., Gupta, A.K., and Singh, R.K. 2010. Equine influenza outbreak in India (2008-09): virus isolation, sero-epidemiology and phylogenetic analysis of HA gene. Vet. Microbiol. 143: 224-237. [Medline] [CrossRef]

41. Waddell, G.H., Teigland, M.B., and Sigel, M.M. 1963. A new influenza virus associated with equine respiratory disease. J. Am. Vet. Med. Assoc. 143: 587-590. [Medline]

42. Wilson, W.D. 1993. Equine influenza. Vet. Clin. North Am. 
Equine Pract. 9: 257-282. [Medline]

43. Wood, J., Smith, K.C., Daly, J.M., and Newton, J.R. 2007. Viral infections of the equine respiratory tract. pp.287-326. In: Equine Respiratory Medicine and Surgery (McGorum, B.C., Dixon, P.M., Robinson, N.E., and Schumacher, J. eds.), Elsevier, Philadelphia.

44. Yamanaka, T., Niwa, H., Tsujimura, K., Kondo, T., and Matsumura, T. 2008. Epidemic of equine influenza among vaccinated racehorses in Japan in 2007. J. Vet. Med. Sci. 70: 623-625. [Medline] [CrossRef]

45. Yondon, M., Heil, G.L., Burks, J.P., Zayat, B., Waltzek, T.B., Jamiyan, B.O., McKenzie, P.P., Krueger, W.S., Friary, J.A., and Gray, G.C. 2013. Isolation and characterization of H3N8 equine influenza A virus associated with the 2011 epizootic in Mongolia. Influenza Other Respi. Viruses 7: 659-665. [Medline] [CrossRef] 